\title{
Peran Pemerintah dalam Pengelolaan Objek Wisata di Kecamatan Pineleng Kabupaten Minahasa
}

\author{
$1{ }^{\text {st }}$ Sisca B. Kairupan \\ UNIMA \\ Tondano, Indonesia \\ siscakairupan@unima.ac.id \\ $2{ }^{\text {nd }}$ Marthinus Mandagi \\ UNIMA \\ Tondano, Indonesia \\ marthinusmandagi@unima.ac.id
}

Abstrak - Adapun tujuan dari penelitian ini adalah : (1) Untuk mengetahui Bagaimanakah Peran Pemerintah dalam hal pengelolaan objek wisata di Kecamatan Pineleng Kabupaten Minahasa Kabupaten Minahasa, (2) Untuk mengetahui Faktor-faktor yang mempengaruhi dalam Pengelolaan Objek wisatadi Kecamatan Pineleng Kabupaten Minahasa.

Penelitian ini menggunakan metode kualitatif dan bertempat di Kali Selata Kecamatan pineleng dan menghasilkan peran pemerintah daerah (Dinas Pariwisata) dalam pengelolaan potensi pariwisata di Kecamatan Pineleng Kabupaten Minahasa sudah berjalan dengan baik. Hal ini dapat dilihat dari peran pemerintah dalam pengembangan pariwisata yang mencakup Koordinator, peran yang dilakukan pemerintah sebagai koordinator yaitu melakukan koordinasi dengan Instansi dan pembuatan strategi. Fasilitator, peran yang dilakukan pemerintah yaitu, menyediakan sarana dan prasaran dan menciptakan strategi promosi. Stabilitator, peran pmerintah sebagai stabilitator belum bagus karena pemerintah daerah dalam hal ini Dinas Pariwisata Kecamatan Pineleng Kabupaten Minahasabelum melibatkan pihak investor dan pihak swasta untuk ikut serta dalam pengelolaan pariwisata, pemerintah hanya melibatkan masyarakat dalam pengelolaanya. Motivator, peran yang di lakukan pemerintah yaitu: memberdayakan msyarakat.

Kata kunci: objek wisata, pineleng, pengelolaan

\section{INTRODUCTION}

Indonesia merupakan Negara yang memiliki keanekaragaman daya tarik mulai dari kebudayaan, adat istiadat, kekayaan alam berupa emas, minyak, flora dan fauna, dan keindahankeindahan alam lainnya yang dapat menjadikan Indonesia menjadi salah satu tujuan wisata yang paling diminati oleh wisatawan baik domestik maupun mancanegara. Dalam UU no 10 tahun 2009 pasal 1 ayat (5) daya tarik wisata adalah segala sesuatu yang memiliki keunikan, keindahan, dan nilai yang berupa keanekaragaman kekayaan alam, budaya, dan hasil buatan manusia yang menjadi sasaran atau tujuan kunjungan wisatawan.

Dalam Era globalisasi pada zaman sekarang ini bidang pariwisata memiliki manfaat yang sangat besar dalam meningkatkan nilai finansial yang diperoleh bagi suatu Negara Nugroho (2011). Indonesia merupakan Negara yang memiliki keanekaragaman daya tarik wisata yang tersebar di berbagai daerah, yang tentunya memiliki keunikan-keunikan tersendiri Pitana dan Diarta (2009). Salah satunya Objek wisata Air terjun Tapahan Telu yang berada di Desa Kali Selata Kecamatan Pineleng Kabupaten Minahasa.

Objek wisata Air terjun yang berada di Desa Kali Selatan, memiliki ketinggian 20-60 meter. Objek wisata ini pula memiliki keadaan alam yang sangat sejuk dan pemandangan dari tanjakan kita dapat melihat hamparan bukit dan laut Sulawesi, serta berdekatan dengan daerah Kota Manado dengan jarak tempuh hanya sekitar 30 
menit sampai ke pintu masuk Air terjun. Objek wisata Air terjun Tapahan Telu yang berada di Desa Kali Selatan merupakan Objek wisata Air terjun yang sangat unik karena merupakan Air terjun bertingkat yang memiliki Tiga Tingkatan sehingga masyarakat sekitar sering menyebutnya 'Tapahan Telu', yang berarti Tiga tingkatan Air terjun. Untuk menuju ke Objek wisata Air terjun Kali pengunjung dapat memilih dua jalan alternative yaitu jalan dari arah Kota Tomohon dimana pengunjung dapat melalui Jalan Resort Onong's Place dan dari arah Kota Manado pengunjung dapat melalui Jalan Gerbang masuk Tugu Makam Pahlawan Tuanku Imam Bonjol. Berdasarkan pengamatan, para wisatawan yang berkunjung di Objek wisata Air terjun Tapahan Telu bukan hanya pengunjung dalam negeri saja namun ada pula pengunjung yang berasal dari luar negeri yang merasa tertarik dengan pesona keindahan Air terjun Kali. Objek wisata Air terjun kali merupakan aset wisata yang memiliki nilai jual yang sangat besar dan akan sangat bermanfaat apabila dikelola sebaik mungkin.

Namum melihat kondisi Fasilitas dan Sarana prasarana lainnya yang dalam kondisi tidak terawat, seperti terlihat dari depan tempat loket karcis dan papan nama gerbang pintu masuk Objek wisata Air terjun Tapahan Telu dalam keadaan yang berdebu serta cat dan tulisan yang ada di papan nama yang sudah mulai luntur, kemudian terlihat pula keadaan jalan setapak dan anak-anak tangga yang licin dan berlumut, pospos peristirahatan yang penuh dengan coretan dan keadaan atap yang tidak utuh lagi, toilet umum yang kotor dan penuh coretan, tidak tersedianya tempat sampah, serta kurang tersedianya kios-kios makanan untuk para pengunjung. Tentunya hal tersebut sangat dikeluhkan oleh para pengunjung dan masyarakat sekitar yang sangat menyayangkan hal tersebut. Kondisi ini diperburuk pula karena keadaan akses jalan pada saat memasuki Desa Kali sampai pada pintu gerbang Air terjun Tapahan Telu dalam keadaan yang kurang baik, karena kondisi jalan yang berlubang dan sempit sehingga mempersulit kendaraan para wisatawan menuju Objek wisata tersebut. Pengelolaan Objek wisata perlu dilakukan untuk menciptakan Objek wisata yang diminati para wisatawan sehingga akan berdampak baik untuk meningkatkan perekonomian masyarakat Rakhmat (2013). Pengelolaan Objek wisata selain ditujukan untuk meningkatkan perekonomian masyarakat, juga sebagai upaya untuk pelestarian fungsi lingkungan hidup Kodyat, H, (1996); Sebagaimana tercantum dalam Perda No 1 Tahun 2014 tentang Rencana tata ruang provinsi Sulawesi Utara pasal 4 ayat (7) poin a 'Strategi untuk mewujudkan kebijakan peningkatan dan pelestarian fungsi lingkungan hidup, sebagaimana dimaksud dalam Pasal 3 huruf d, terdiri dari: a) mengelola taman wisata alam yang memadukan kepentingan pelestarian dan pariwisata/rekreasi;'

Daerah Minahasa selain dikenal dengan hasil Pangan yang melimpah juga dikenal dengan objek-objek wisata yang memiliki keindahan tersendiri, keindahan objek-objek wisata alam,budaya dll di Daerah Minahasa tentunya memiliki keuntungan tersendiri bagi Pengembangan Pariwisata di Minahasa. Pengelolaan Objek Wisata Air terjun Tapahan Telu merupakan hal yang sangat perlu dilakukan, mengingat juga bahwa sektor Pariwisata merupakan salah satu sector yang memiliki peluang yang sangat besar untuk menghasilkan pendapatan daerah. Pemerintah Daerah dalam hal ini sebagai pengelolaan Objek Wisata Air terjun Tapahan Telu di Desa Kali Selatan Kecamatan Pineleng Kabupaten Minahasa tentunya harus turut serta dalam upaya dalam pengelolaan Objek Wisata tersebut dengan harapan kiranya dapat bermanfaat nantinya untuk kemajuan Daerah.

Berdasarkan keadaan Objek wisata Air terjun Tapahan Telu dapat dilihat bahwa kurangnya Pengelolaan yang dilakukan merupakan salah satu penyebab keadaan Objek wisata tersebut menjadi dalam keadaan yang tidak terawat. Kurangnya Pengelolaan yang dilakukan tentunya berdampak buruk bagi kunjungan para wisatawan yang akan semakin berkurang sehingga akan berdampak 
buruk bagi perekonomian masyarakat. Pengelolaan memiliki kaitan yang sangat erat dengan kegiatan manajemen, karena dalam setiap pengelolaan meliputi fungsi-fungsi, prinsipprinsip dan unsur-unsur manajemen sebagai penunjang berlangsungnya pengelolaan tersebut.

Menurut Terry dalam Sabardi (2008) Manajemen merupakan sebuah proses yang khas, yang terdiri dari tindakan-tindakan: perencanaan, pengorganisasian, pelaksanaan dan pengawasan yang dilakukan untuk menentukan serta mencapai sasaran-sasaran yang telah ditetapkan melalui pemanfaatan sumber daya manusia dan sumbersumber lainnya."

Melihat permasalahan yang telah diuraikan diatas mendorong peneliti melakukan penelitian dengan judul 'peran pemerintah dalam pengelolaan objek wisata di kecamatan pineleng kabupaten minahasa'

\section{RESEARCH METHOD}

Pendekatan yang digunakan oleh peneliti adalah pendekatan Kualitatif, penelitian ini dilakukan dalam keadaan alamiah (natural setting). Menurut (sugiyono, 2014), penelitian kualitatif adalah penelitian yang digunakan untuk meneliti pada kondisi objek alamiah, sebagai lawannya adalah eksperimen, dimana peneliti adalah sebagai instrument kunci, teknik pengumpulan data dilakukan secara triangulasi (penggabungan), analisis data bersifat induktif, dan hasil penelitian kualitatif lebih menekankan makna daripada generalisasi.

\section{RESULT AND CONCLUSION}

Pariwisata merupakan salah satu aspek yang berpearan pentimg dalam meningakatkan pendapatan setiap daerah. Undanng-Undang Nomor 10 Tahun 2009 Tentang kepariwisataan menjelaskan bahwa kepariwisataan diperlukan untuk mendorong pemerataan, kesempatan berusaha dan memperoleh manfaat serta mampu mengahdapi tantangan perubahan kehidpuan lokal, nasional dan global.

Pengelolaan potensi pariwisata di Kecamatan Pineleng Kabupaten Minahasa menjadi perhatian khusus pemerintah, hal ini tercermin dalam arah kebijakan (visi) pemerintah bahwa tujuan utama pembangunan pariwisata adalah menjadikan sebagai destinasi kedua setelah Bali. Di sisi lain, dukungan masyarkat Kecamatan Pineleng Kabupaten Minahasasangat posistif memeberikan respon pengembangan pariwisata.

Sebagai salah satu aspek yang berpotensi dalam meningkat pendapatan daearah, pariwisata harus dikelola dengan baik. Untuk itu perlu adanya peran dari pemerintah dalam pengelolaan yang terencana secara menyeluruh.

Dengan menggunakan teori yang dikemukakan oleh ahli tentang pengelolaan pariwisata, maka dari itu pada penelitian ini penulis menggunakan teori pengelolaan pariwisata yang di kemukan oleh Blakely: koordinator, fasilitator, stimulator, motivator.

a. Koordinator

Sebagai koordinator pemerintah daerah dapat menetapkan kebijaksan atau strategi bagi pembangunan daerah dan merangkul semua komponen masyarkat untuk menjadi aktor utama dalam pemabangunan.

Mencakup peran pemerintah selaku pengkoordinasi dan asosiasi di bidang pariwisata selaku penyelenggara pariwisata, baik ditingkat lokal,regional, maupun internasional. Sektor ini biasanya menangani perencanaan dan fungsi manajerial untuk membuat sistem koordinasi antara seluruh sektor dalam industrypariwisata.

b. Fasilitator

Pemerintah sebagai fasilitator yaitu menciptakan kondisi yang kondusif bagi pelaksana pembangunan daerah. Sebagai faslitator pemerintah bergerak dibidang pendampingan melalui pelatihan, 
pendidikan dan peningkatan keterampilan serat dibidang pendanaan atau permodalan kepada masyarakat yang di berdayakan.

Dalam membangun pariwisata Dinas Pariwisata Kecamatan Pineleng Kabupaten Minahasa bertanggung jawab memfasilitasi masyarakat untuk bersama mengelola pariwisata sesuai dengan kebutuhan yang diperlukan dalam hal sarana dan prasarana yang mendukung efektivitas program atau kegiatan. Pemerintah dalam hal ini Dinas Pariwisata menyediakan lahan untuk masyarkat sekitar objek wisata untuk tempat membuka usaha.

c. Stimulator

Menurut Blakely Stimulator adalah pemerintah dapat mmenciptakan strategi untuk membangun objekdan daya tarik wisata. Dinas kebudayaan dandaya tarik wisata menyusun strategiyang akan dilaksanakan dalam rangkapengembangan objek wisata. Disini pemerintah melibatkan dan bekerjasamadengan masyarakat, dengan membangunsarana seperti tempat untuk berjualan sepertikantin sehingga mendatangkan keuntunganbaik untuk pemerintah daerah, masyarakatsetempat, dan wisatawan.

Berdasarkan hasil observasi dan wawancara Peran Dinas pariwisata Kecamatan Pineleng Kabupaten Minahasa sebagai motivator menstimulasi segenap pemangku kepentingan untuk terlibat dalam pengembangan objek daya tarik wisata. Pemerintah juga melakukan pembinaan kepada masyarakat yang diberdayakan di objek wisata, masyarakat di ajak bagaimana menjaga dan mengelola objek wisata agar tetap lestari dan menarik hati para pengunjung. Namun di sisi lain pemerintah belum melibatkan pihak swasta baik investor atau perusahaanperusahaan dalam pengelolaan potesni pariwisata yang ad di Kecamatan Pineleng Kabupaten Minahasa. Pemerintah belum melibatkan pihak investor karen pengambil kebijakan di Kecamatan Pineleng Kabupaten Minahasa belum menerima tawaran dari investor.

d. Motivator

Dalam pembangunan pariwisata peran pemerintah sebagai motivator diperlukan agar geliat usaha pariwisata terus berjalan. Investor, masyarakat serta pengusaha dibidang pariwisata merupakan sasaran utama yang perlu untuk terus diberikan motivasi agar perkembangan pariwisata dapat berjalan dengan baik. Tidak dapat dipungkiri bahwa proses pengelolaan dan pengembangan pariwisata tidak lepas dari dukungan masyarakat ataupun pengusaha di bidang pariwisata.

Berdasarkan penelitian yang telah dilakukan, peran pemerintah daerah dalam memotivasi masyarkat untuk ikut dalam pengelolaan pariwisata yang dilakukan dengan berbagai upaya seperti : memberdayakan masyarkat yang tinggal di sekitar objek wisata hal ini diwujudkan melalui pemberian lahan kepada masyarkat tanpa memungut biaya, selain itu masyarkat juga di berikan motivasi melalui promosi pemasaran. Upaya pemerintah tersebut mendapat respo baik dari masyarakat.

\section{Peran Pemerintah Daerah dalam Pengembangan Destinasi Wisata di Kecamatan Pineleng Kabupaten Minahasa}

1. Perencanaan Pariwisata

a. peningkatan daya tarik wisata

b. penyediaan fasilitas rumah makan

c. meningkatkan aksesibilitas berupa alat transportasi 

d. perencanaan dalam meningkatkan promosi untuk menarik wisatawan.

2. Pembangunan Pariwisata

Disbudparpora sudah berupaya untuk mengembangkan Kecamatan Pineleng Kabupaten Minahasa melalui pembangunan sarana dan prasarana pariwisata. Pembangunan tersebut dinilai sudah cukup baik karena selain dapat digunakan wisatawan juga dapat dimanfaatkan oleh masyarakat sekitar destinasi wisata. untuk melakukan aktivitasnya dalam memenuhi kebutuhan sehari-hari Sesuai dengan kondisi saat ini Pemerintah perlu melakukan perencanaan pembangunan yang tepat untuk pariwisata bahari.

\section{Kebijakan Pariwisata}

Pemerintah dalam pengimplementasian kebijakan Pariwisata salah satunya yaitu melalui pembangunan infrastruktur yang ada di destinasi wisata Kecamatan Pineleng Kabupaten Minahasa. Infrastruktur tersebut berupa pengadaan jembatan penyebrangan menuju destinasi wisata Kecamatan Pineleng Kabupaten Minahasa. Jembatan tersebut selain dapat digunakan untuk kemudahan akses wisatawan dalam mengunjungi Kecamatan Pineleng Kabupaten Minahasa.

\section{Peraturan Pariwisata}

Pemerintah tidak memiliki peraturan tertulis terkait destinasi wisata tersebut. Pemerintah dalam mengatur kegiatan wisata tersebut masih sebatas himbauan secara lisan yang dilakukan untuk mengatur wisatawan yang berkunjung melalui penyedia jasa perjalanan pariwisata Tour and Travel. Masih belum adanya peraturan tertulis dari Pemerintah dalam mengatur kegiatan pariwisata di destinasi wisata Kecamatan Pineleng
Kabupaten Minahasadikarenakan Disbudparpora memberikan wewenang kepada masyarakat serta perangkat desa dalam membuat sendiri peraturanperaturan yang nantinya akan ditelurkan kedalam peraturan desa.

\section{CONCLUSION}

Berdasarkan hasil penelitian yang ini dapat disimpulkan bahwa peran pemerintah daerah (Dinas Pariwisata) dalam pengelolaan potensi pariwisata di Kecamatan Pineleng Kabupaten Minahasa sudah berjalan dengan baik. Hal ini dapat dilihat dari peran pemerintah dalam pengembangan pariwisata yang mencakup Koordinator, peran yang dilakukan pemerintah sebagai koordinator yaitu melakukan koordinasi dengan Instansi dan pembuatan strategi. Fasilitator, peran yang dilakukan pemerintah yaitu, menyediakan sarana dan prasaran dan menciptakan strategi promosi. Stabilitator, peran pmerintah sebagai stabilitator belum bagus karena pemerintah daerah dalam hal ini Dinas Pariwisata Kecamatan Pineleng Kabupaten Minahasabelum melibatkan pihak investor dan pihak swasta untuk ikut serta dalam pengelolaan pariwisata, pemerintah hanya melibatkan masyarakat dalam pengelolaanya. Motivator, peran yang di lakukan pemerintah yaitu: memberdayakan msyarakat.

\section{ACKNOWLEDGMENT}

Terima kasih disampaikan kepada Pimpinan Lembaga Penelitian dan Pengabdian Kepada Masyarakat (LPPM) Universitas Negeri Manado yang telah menyetujui perencanaan penyelesaian penelitian sehingga artikel ini dapat diselesaikan. 


\section{REFERENSI}

[1] Sugiono, Metode Penelitian, Metode Penelitian, 2014

[2] H. Kodyat, Sejarah Pariwisata dan Perkembangan di Indonesia, UI-Press:jakarta, Grasindo, Jakarta, 1996

[3] Nugroho Iwan, Ekowisata dan Pembangunan Berkelanjutan, Pustaka Pelajar, Yogyakarta, 2011

[4] Pitana dan Diarta, Pengantar Ilmu Pariwisata, Yogyakarta, 2019

Rakhmat, Dimensi Strategis Manajemen Pembangunan, Graha Ilmu, Yogyakarta, 2013 